\title{
Effect of cobalt (nickel) oxide on the properties of zinc-titanium sorbents for high temperature desulphurization of model coal gas
}

\author{
M. Chomiak ${ }^{1} \cdot$ J. TrawCzyński $^{1} \cdot$ M. Zawadzki ${ }^{2}$ (I)
}

Received: 6 May 2020 / Revised: 23 June 2021 / Accepted: 25 June 2021 / Published online: 6 July 2021

(c) The Author(s) 2021

\begin{abstract}
$\mathrm{Zn}-\mathrm{Ti}-\mathrm{Co}(\mathrm{Ni})$ sorbents for $\mathrm{H}_{2} \mathrm{~S}$ removal from model hot coal were prepared and characterized. Effects of cobalt (Co) and nickel $(\mathrm{Ni})$ on the sorbents texture, structure, $\mathrm{H}_{2} \mathrm{~S}$ sorption capacity and regeneration properties were determined. $\mathrm{TiO}_{2}$ formed mixed metal oxides with $\mathrm{CoO}$ and $\mathrm{NiO}$ in the fresh sorbents, while $\mathrm{TiO}_{2}$ and nanocrystalline sulfides of $\mathrm{Zn}, \mathrm{Co}, \mathrm{Ni}$ were found in sulphided ones. The oxidative regeneration of sulphided sorbents re-formed mixed oxides. Sorption capacity of studied materials increased along with an increase of the amount of added $\mathrm{Co}(\mathrm{Ni})$ and also with the number of work cycles. Co-doped $\mathrm{Zn}-\mathrm{Ti}$ materials adsorbed up to $244 \%$ more sulfur than these of $\mathrm{Zn}-\mathrm{Ti}$, while Ni-doped materials adsorbed ca. twice more $\mathrm{H}_{2} \mathrm{~S}$ than the corresponding Co-doped sorbents. The addition of $\mathrm{Co}(\mathrm{Ni})$ decreased the temperature of $\mathrm{ZnS}$ oxidation. The catalytic effect of the $\mathrm{Co}(\mathrm{Ni})$ oxides on the oxidation of $\mathrm{ZnS}$ was suggested.
\end{abstract}

Keywords Hot coal gas $\cdot$ Desulphurization $\cdot$ Hydrogen sulphide $\cdot$ Sorbent $\cdot$ Regeneration

\section{Introduction}

The present technologies of energy production based on coal combustion, due to environmental reasons and low efficiency, are of low effectiveness. Therefore, the development of better technologies such as supercritical fluidised-bed boilers or technologies based on coal gasification (IGFC, IGCC) is needed. An important problem associated with coal gasification is desulphurization of the obtained coal gas. Currently, the removal of hydrogen sulphide is carried out by wet methods, which requires gas cooling and therefore reduces the efficiency of the entire IGCC installation. The data from a demonstration plant indicated ca. $10 \%$ relative increase in the efficiency of the IGCC system as the result of a high temperature desulphurization process application (US Department of Energy 2015). Desulphurization of hot

M. Zawadzki

m.zawadzki@intibs.pl

1 Department of Fuels Chemistry and Technology, Wrocław University of Science and Technology, Gdańska 7/9 Str., 50-344 Wrocław, Poland

2 Department of Nanomaterials Chemistry and Catalysis, Institute of Low Temperature and Structure Research, Polish Academy of Sciences, PO Box 1410, 50-950 Wrocław, Poland coal gas has been studied for a number of years; however, a suitable sorbent has still not been developed. Simple and mixed oxides (e.g., of $\mathrm{Zn}, \mathrm{Fe}, \mathrm{Cu}, \mathrm{Mn}, \mathrm{Ce}, \mathrm{Co}$ ) are suggested for this purpose (Meng et al. 2010). For improving sorption and regeneration properties as well as number of operating cycles of these materials, addition of $\mathrm{V}, \mathrm{Co}, \mathrm{Ni}$ or $\mathrm{Cu}$ oxides is considered (Meng et al. 2010; Atimtay and Harrison 1998; Chomiak and Trawczyński 2015; Pineda et al. 1997).

Zinc based materials show a high reactivity in sulphidation and are easily regenerate in an oxidizing atmosphere. Therefore, they are considered as suitable regenerable sorbents. The disadvantages of zinc sorbents include progressive decay in performance, associated with the lack of stability during sulphidation and incomplete conversion during regeneration. The stability of $\mathrm{ZnO}$ at medium temperatures was studied by Bezverkhy et al. (2012). They stated that, during sulphidation at 523-623 K, due to the Kirkendall effect, $\mathrm{Zn}^{2+}$ ions diffuse to the grain surface. The metallic zinc accumulated on the surface can evaporate at a high sorption temperature. A $\mathrm{ZnO}$ sorbent mixed with a copper oxide $\left(\mathrm{Cu}_{0.06} \mathrm{Zn}_{0.94} \mathrm{O}\right)$ was sulphated, and migration of $\mathrm{S}^{2-}$ ions inside the sorbent grain was stated. The authors explained this phenomenon by formation of anionic vacancies on the grain surface which accelerate diffusion of sulfur ions inside the grain and improve its sorption capacity. During regeneration, the sulfur migrates from the grain interior 
to its surface; the intensity of this process strongly depends on the temperature and the type of the added metal. Sorption and regeneration properties of zinc-based sorbents are improved by addition of the other components active in $\mathrm{H}_{2} \mathrm{~S}$ sorption, such as $\mathrm{Ni}, \mathrm{Co}, \mathrm{Cu}, \mathrm{Fe}, \mathrm{Mn}$ or inerts, e.g.: $\mathrm{La}_{2} \mathrm{O}_{3}$, $\mathrm{ZrO}_{2}$, bentonite, $\mathrm{SiO}_{2}$ (Meng et al. 2010; Atimtay and Harrison 1998; Chomiak and Trawczyński 2015; Pineda et al. 1997). Results of theoretical studies of Girard et al. (2014) showed that the concentration of $\mathrm{H}_{2} \mathrm{~S}$ under equilibrium conditions with $\mathrm{NiO}$ is significantly lower than that in the case of CoO. Park et al. (2010) showed that, at medium temperature, the $\mathrm{Zn}$-Ti sorbents doped with $\mathrm{Ni}$ are characterised by a higher sorption capacity than those containing of Co.

Complete regeneration of sulphided sorbent is a crucial aspect. Factors affecting the course of regeneration, formation of sulphates and the number of possible work cycles are still not well understood. Ensuring a stable sorption capacity during sulphidation/regeneration cyclic work is another challenge. Park et al. (2010) suggested that the admixture of $\mathrm{Ni}$ or Co oxides to $\mathrm{Zn}$-sorbent facilitates regeneration, probably due to a catalytic effect. Girard et al. (2015) studied regeneration of $\mathrm{Zn}-\mathrm{Mo}$ sorbent and found that the oxidation of $\mathrm{MoS}_{2}$ apparently lowers the temperature of $\mathrm{ZnS}$ oxidation. Despite the development that was made in the studies on sorbents for hot coal gas desulphurization, knowledge of the effect of $\mathrm{Co}(\mathrm{Ni})$ addition on the properties of $\mathrm{Zn}-\mathrm{Ti}$ (ZT) sorbents is still incomplete. To the best of the authors' knowledge, no papers considering the effect of the Co (Ni) component on sorption/regeneration performance of ZT sorbents have been published so far.

The aim of this study was to determine the effect of Co or Ni oxide addition on the desulfurization and regeneration properties of ZT based sorbents. Effects of the cyclic desulphurization/regeneration of $\mathrm{Co}(\mathrm{Ni})$ doped $\mathrm{ZT}$ sorbent on its texture, morphology, phase composition, capacity of $\mathrm{H}_{2} \mathrm{~S}$ sorption, as well as on the regenerative properties, are presented and discussed. The composition of the model coal gas used in our study approximately corresponded to that of gas from coal gasification.

\section{Materials and methods}

\section{Sorbents preparation}

Sorbents were prepared by a slurry concentration method (Zdrazil 2001) using the following raw materials: $\mathrm{Zn}\left(\mathrm{NO}_{3}\right)_{2} \times 6 \mathrm{H}_{2} \mathrm{O}$ ( $\geq 99 \%$; Avantor); $\mathrm{Co}\left(\mathrm{NO}_{3}\right)_{2} \times 6 \mathrm{H}_{2} \mathrm{O}$ ( $\geq 99 \%$; Acros Organics); $\mathrm{Ni}\left(\mathrm{NO}_{3}\right)_{2} \times 6 \mathrm{H}_{2} \mathrm{O}$ ( $\geq 99 \%$; Acros Organics); $\mathrm{TiO}_{2}$ ( $\geq 99 \%$; Panareac); natural clay (Drużkowska). Example of the synthesis procedure: $15 \mathrm{~g}$ of $\mathrm{TiO}_{2}$ were mixed with $300 \mathrm{~cm}^{3}$ of an aqueous solution of $\mathrm{Zn}\left(\mathrm{NO}_{3}\right)_{2} \times 6 \mathrm{H}_{2} \mathrm{O}$ and $\mathrm{Co}\left(\mathrm{NO}_{3}\right)_{2} \times 6 \mathrm{H}_{2} \mathrm{O}(37.2 \mathrm{~g}$ and
10.92 g respectively; $\mathrm{Zn}: \mathrm{Co}: \mathrm{Ti}=1: 0.125: 1.5)$ and stirred for $2 \mathrm{~h}$. Then water was evaporated and the resultant mass was dried in an oven at $423 \mathrm{~K}$ for $12 \mathrm{~h}$. Dry material was crushed and calcined under air flow for $6 \mathrm{~h}$ at $1173 \mathrm{~K}$. The obtained material was crushed once again, milled for $1 \mathrm{~h}$ in a ball mill with a binder (Drużkowska clay) at a weight ratio 4:1, and finally calcined at $1173 \mathrm{~K}$ for $6 \mathrm{~h}$. Prepared sorbents were denoted as ZT; ZTCo1; ZTCo2; ZTCo3; ZTNi1; ZTNi2 and ZTNi3. The composition of the prepared sorbents (expressed as a ratio of $\mathrm{Zn}: \mathrm{Co}(\mathrm{Ni}): \mathrm{Ti})$ is presented in Table 1.

\section{Apparatus and procedures}

Tests of the model coal gas desulphurization, as well as sorbent regeneration, were carried out in a tubular quartz reactor $(\mathrm{d}=8 \mathrm{~mm} ; \mathrm{L}=80 \mathrm{~cm})$ placed in a three-zone tube furnace. $1.5 \mathrm{~cm}^{3}$ of adsorbent particles of $0.4-0.8 \mathrm{~mm}$ were loaded into a corundum layer of the reactor. The temperature was controlled below and above the sorbent bed. The sorbent bed was heated $(10 \mathrm{~K} / \mathrm{min})$ under nitrogen flow up to $873 \mathrm{~K}$, then nitrogen was switched to a model coal gas. Desulphurization was performed using a mixture composed of: $\mathrm{H}_{2}-25$ vol. \%; $\mathrm{CO}-49.5$ vol. $\%, \mathrm{CO}_{2}-20$ vol. $\%$; $\mathrm{H}_{2} \mathrm{~S}-0.5$ vol. $\%$; $\mathrm{CH}_{4}-5$ vol.\%. The concentration of $\mathrm{H}_{2} \mathrm{~S}$ was monitored online (every $15 \mathrm{~min}$ ) using a gas chromatograph (PerkinElmer, Clarus 500) equipped with TCD and FPD detectors.

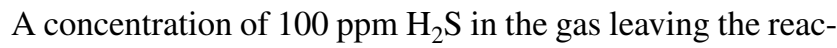
tor was considered as the point of bed breakthrough.

For the calculation of $\mathrm{H}_{2} \mathrm{~S}$ sorption capacity the following formulas were used:

$$
\begin{aligned}
& C_{S}=\frac{m_{S a d s .}}{m_{\text {sorb. }}} \times 100=\frac{\left[\frac{P_{H_{2} S}^{\text {ads. }}}{P_{H_{2} S}^{\text {com }}} \times \sum_{0}^{t_{0}} n_{H_{2} S}^{i n}\right] \times M_{S}}{m_{\text {sorb. }}} \times 100 \\
& =\frac{\left[\frac{\int_{0}^{t_{0}}\left(C_{H_{2} S}^{i n}-C_{H_{2} S}^{\text {out }}\right) d t}{\int_{0}^{t_{0}} C_{H_{2} S}^{i n} d t} \times \sum_{0}^{t_{0}} n_{H_{2} S}^{i n}\right] \times M_{S}}{m_{\text {sorb. }}} \times 100
\end{aligned}
$$

where $C_{S}$ is the mass of sulphur adsorbed by $100 \mathrm{~g}$ of sorbent [gS/100 g]; $m_{\text {Sads. }}$ is the mass of sulphur adsorbed through

Table 1 Sorbents composition

\begin{tabular}{ll}
\hline Sorbent & $\begin{array}{l}\text { Atomic ratio } \\
\text { Zn:Me:Ti }\end{array}$ \\
\hline ZT & $1: 0: 1.5$ \\
ZTCo1 & $1: 0.125: 1.5$ \\
ZTCo2 & $1: 0.25: 1.5$ \\
ZTCo3 & $1: 0.35: 1.5$ \\
ZTNi1 & $1: 0.125: 1.5$ \\
ZTNi2 & $1: 0.25: 1.5$ \\
ZTNi3 & $1: 0.35: 1.5$ \\
\hline
\end{tabular}


the bed [g]; $m_{\text {sorb. }}$ is the sorbent mass [g]; $P_{H_{2} S}^{a d s}$ is the surface area of the adsorbed hydrogen sulphide [ppmv h]; $P_{\mathrm{H}_{2} \mathrm{~S}}^{\mathrm{com}}$ is the surface area of introduced hydrogen sulphide [ppmv h]; $\sum_{0}^{t_{0}} n_{H_{2} S}^{i n}$ is the amount of hydrogen sulphide introduced into the reactor until the breakthrough of the bed [mol]; $C_{\mathrm{H}_{2} S}^{\text {in }}$ is the concentration of hydrogen sulphide fed to the reactor [ppmv]; $\mathrm{C}_{\mathrm{H}_{2} \mathrm{~S}}^{\mathrm{S}}$ is the concentration of the hydrogen sulphide leaving the reactor [ppmv]; $M_{S}$ is the molar mass of sulphur [g/mol].

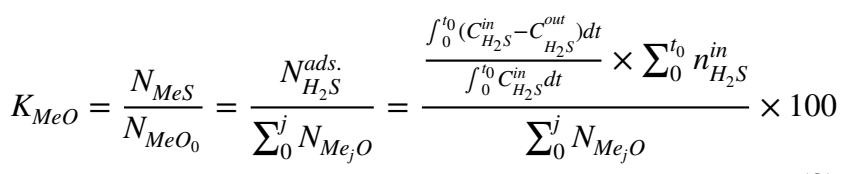

where $K_{M e O}$ is the active component conversion (oxides to sulphides) [\%]; $N_{M e S}$ is the amount of metal sulphides [mol]; $\mathrm{N}_{\mathrm{MeO}_{0}}$ is the amount of metal oxides active in the $\mathrm{H}_{2} \mathrm{~S}$ sorption [mol]; $\mathrm{N}_{\mathrm{H}_{2} \mathrm{~S}}^{\text {ads }}$ is the amount of adsorbed hydrogen sulphide [mol]; $\sum_{0}^{j} N_{M e_{j} O}$ is the sum of the cardinality of active sites in the sorption metal oxides, where $j$ ingredients are active in sorption [mol].

$W_{H_{2} S}=\frac{P_{H_{2} S}^{\text {in }}-P_{H_{2} S}^{\text {out }}}{P_{H_{2} S}^{\text {in }}} \times 100=\frac{\int_{0}^{t_{0}}\left(C_{H_{2} S}^{\text {in }}-C_{H_{2} S}^{\text {out }}\right) d t}{\int_{0}^{t_{0}} C_{H_{2} S}^{\text {in }} d t} \times 100$

where $W_{\mathrm{H}_{2} S}$ is the degree of $\mathrm{H}_{2} \mathrm{~S}$ removal from the gas, until the bed breakthrough (i.e., after $t_{0}$ ) [\%].

After reaching the breakthrough point, the bed was flushed with nitrogen and optionally quenched under $\mathrm{N}_{2}$ flow. Regeneration was carried out using 3 vol. $\%$ of $\mathrm{O}_{2}$ in $\mathrm{N}_{2}\left(\mathrm{GHSV}=24000 \mathrm{~h}^{-1}\right)$. The concentration of $\mathrm{SO}_{2}$ was determined using a Mulator 610 (Maihak) analyser.

The regeneration of spent sorbents was performed according to two different procedures. The first procedure (Procedure I) included a rapid temperature rise from room temperature to $703 \mathrm{~K}$; then the bed was heated up to $923 \mathrm{~K}$ (at $2 \mathrm{~K} / \mathrm{min}$ rate) and held at this temperature. In the second procedure of regeneration (Procedure II), in the first stage, sorbents were regenerated at $703 \mathrm{~K}$ (or $793 \mathrm{~K}$, until the rate of $\mathrm{SO}_{2}$ emission decline was $<5 \mathrm{ppm} / \mathrm{min}$ ); then the temperature was ramped up to $923 \mathrm{~K}(2 \mathrm{~K} / \mathrm{min})$. Apart from these two procedures, some regeneration tests were performed under isothermal conditions, i.e., sorbent was heated under nitrogen flow up to the fixed temperature and, when it was reached, the nitrogen was replaced with 3 vol. $\%$ of $\mathrm{O}_{2}$ in $\mathrm{N}_{2}$.

In multicycle tests, after sulphidation the sorbet was allowed to cool down to ambient temperature and then regeneration according to the indicated procedure was performed. The regenerated sorbent was cooled down to ambient temperature and then the next cycle of sulphidation/regeneration was started.

\section{Characterisation}

The phase composition of the studied materials was determined by X-ray powder diffraction (XRD), using an X'Pert Pro diffractometer (PANalytical Ltd.) with $\mathrm{CuK}_{\alpha}$ radiation $(\lambda=1.5406 \AA)$. The average crystallite size of the dominant phase was determined from the broadening of the diffraction lines on the basis of the Scherrer equation (Azároff 1968).

The sample morphology was studied by scanning electron microscopy (Jeol JSM-6610LVnx) with an integrated X-ray energy dispersive spectrometer (EDS) (Oxford Aztec Energy). Due to the low electrical conductivity, samples were sputtered with graphite in a vacuum coater.

The texture of the samples was determined using conventional mercury porosimetry (440 Pascal CE Instruments, pressure $200 \mathrm{MPa}$ ), before the test samples were out-gassed at room temperature for $1 \mathrm{~h}$. The pore radius was calculated from the Washburn equation (Washburn 1921).

\section{Results and discussion}

\section{Fresh sorbents}

Powder XRD analyses of fresh sorbents (Figs. 1, 2) showed the presence of $\mathrm{TiO}_{2}(\mathrm{ZT}), \mathrm{Co}_{2} \mathrm{TiO}_{4}(\mathrm{ZTCo} 1 ; \mathrm{ZTCo} 2$; ZTCo3) and $\mathrm{NiZnTiO}_{4}$ (ZTNi1; ZTNi2; ZTNi3). Titania is a main phase occurring in the basic (ZT) sorbent. Addition of $\mathrm{CoO}$ into $\mathrm{ZT}$ leads to the formation of mixed oxides of which $\mathrm{Co}_{2} \mathrm{TiO}_{4}$ is dominant, while in the case of $\mathrm{Ni}$ doped materials, $\mathrm{NiZnTiO}_{4}$ dominates. The unambiguous assignment of X-ray peaks of $\mathrm{Co}_{2} \mathrm{TiO}_{4}, \mathrm{ZnCo}_{2} \mathrm{O}_{4}, \mathrm{Zn}_{2} \mathrm{TiO}_{4}$ and

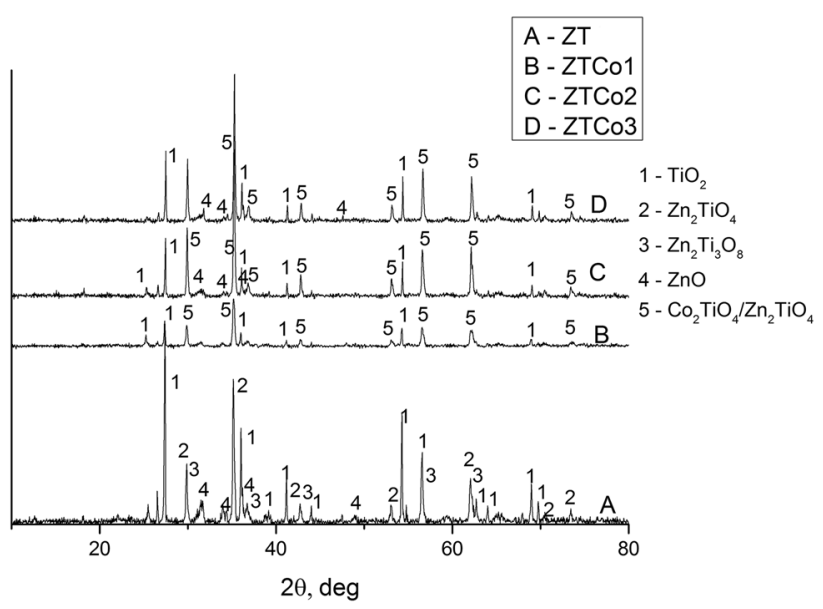

Fig. 1 XRD diffraction patterns of fresh sorbents ZT and ZTCo 


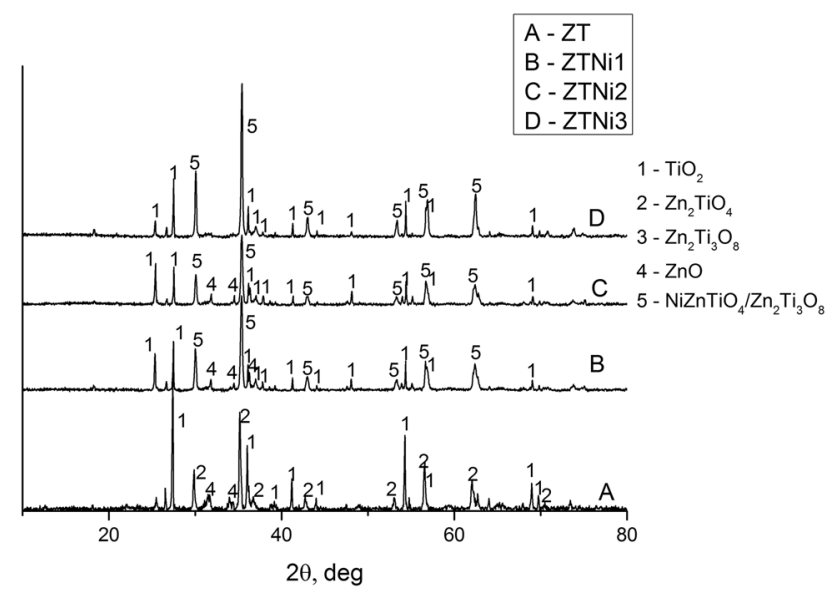

Fig. 2 XRD diffraction patterns of fresh sorbents ZT and ZTNi

$\mathrm{NiZnTiO}_{4}$ is difficult due to the noisiness of the spectrum and partial signal overlapping. This problem is mentioned in numerous reports because it makes it difficult to analyze a phase transformation during cyclic work (Chomiak and Trawczyński 2015; Pineda et al. 1997). There are no signals of $\mathrm{Co}(\mathrm{Ni})$ simple oxides in the XRD patterns, probably due to the large excess of $\mathrm{TiO}_{2}$ used for sorbent preparation. Moreover, the absence of the corresponding diffraction peaks may result from their amorphous or low crystalline state. $\mathrm{ZnO}$ signals are present in the diffraction patterns of most of the tested sorbents. The presence of free $\mathrm{ZnO}$ in the sorbent is undesirable because it is less resistant to the reduction by hydrogen than the mixed oxides containing this element (Lew et al. 1989, 1992). ZnO, CoO and NiO compete in the formation of mixed oxides with $\mathrm{TiO}_{2}$. Co (Ni) oxides form mixed oxides with $\mathrm{ZnO}$ at lower temperatures compared to $\mathrm{TiO}_{2}$ which favors formation of these components and prevent phase separation during regeneration (Hull and Trawczyński 2014). The average crystallite size of the dominant phases slightly increases with increasing amounts of added metal (Table 2).

The sorbents studied exhibit low values of the specific surface area (SSA) and total pore volume regardless of the type and amount of components introduced (Table 2), which results from the high temperature of calcination. The SSA and porosity of ZnTi-based sorbents reported in the literature depend on the synthesis method and generally are not very high. For example, Jung et al. (2005) report for ZnTi-bentonite sorbents $\mathrm{SSA}=8.43 \mathrm{~m}^{2} / \mathrm{g}$ (calcined at $973 \mathrm{~K}$ ) and 3.24 $\mathrm{m}^{2} / \mathrm{g}$ (calcined at $1273 \mathrm{~K}$ ) and pore volumes of 0.26 and 0.31 $\mathrm{cm}^{3} / \mathrm{g}$, respectively, while ZT sorbent prepared by coprecipitation and calcined at $973 \mathrm{~K}$ showed SSA as high as 18.34 $\mathrm{m}^{2} \mathrm{~g}$ and pore volume of $0.89 \mathrm{~cm}^{3} / \mathrm{g}$. The SSA of the ZTNi sorbents lowers and the average pore size increases with increasing content of $\mathrm{Ni}$, while no relationship is observed in the case of Co-doped sorbents. The latter are characterised by a higher average pore size and higher total volume than in the case of ZTNi.

\section{Desulphurization}

Three cycles of sorption/desorption were performed for each sorbent (Table 3, Figs. 3, 4)—regeneration of sulphided sorbents was carried out according to the isothermal procedure at $923 \mathrm{~K}$. The ZT shows the lowest sorption capacity among all studied sorbents-it captured the smallest amount of $\mathrm{H}_{2} \mathrm{~S}$ during the first $(1.6 \mathrm{gS} / 100 \mathrm{~g})$ and subsequent cycles $(1.8$ $\mathrm{gS} / 100 \mathrm{~g}$ ). Addition of Co to ZT leads to materials possessing higher efficiency of $\mathrm{H}_{2} \mathrm{~S}$ removal. For all sorbents the sorption capacity and the conversion of the active components increases with successive operation cycles. The amounts of the sulfur captured by ZT and ZTCo1 during the first cycle differ only slightly. Doubling the amount of added Co (ZTCo1 vs ZTCo2) results in an almost double increase of captured $\mathrm{H}_{2} \mathrm{~S}$. As the Co content increases, the conversion of active components increases, which suggests that the presence of Co promotes the diffusion of sulfide ions into the sorbent grains and consequently the conversion of the active components. A similar effect of $\mathrm{CuO}$ on sulfur ion diffusion in $\mathrm{ZnO}$ has been reported by Bezverkhy et al. (2012). They observed a rapid increase in the size of $\mathrm{ZnS}$ crystallites after doping $\mathrm{ZnO}$ with $\mathrm{Cu}$, compared to un-doped material. They explained this phenomenon by a change in the sulphidation mechanism as a result of the introduction of $\mathrm{Cu}$ into $\mathrm{ZnO}$. Sulfidation of nanosized $\mathrm{ZnO}$ by gaseous $\mathrm{H}_{2} \mathrm{~S}$ proceeds via the outward growth of $\mathrm{ZnS}: \mathrm{Zn}^{2+}$ and $\mathrm{O}^{2-}$ are transferred to the external surface, where the zinc is combined with sulfur

Table 2 Properties of fresh sorbents doped with Co and Ni

\begin{tabular}{llllllll}
\hline Sorbent & ZT & ZTCo1 & ZTCo2 & ZTCo3 & ZTNi1 & ZTNi2 & ZTNi3 \\
\hline Total pore volume, $\mathrm{cm}^{3} / \mathrm{g}$ & 0.196 & 0.273 & 0.296 & 0.267 & 0.189 & 0.223 & 0.188 \\
Specific surface area, $\mathrm{m}^{2} / \mathrm{g}$ & 3.5 & 5.3 & 7.4 & 5.7 & 8.5 & 4.8 & 3.8 \\
Average pore diameter, $\mathrm{nm}$ & 194 & 175 & 141 & 113 & 87 & 91 & 175 \\
\hline Dominant phase & $\mathrm{TiO}_{2}$ & $\mathrm{Co}_{2} \mathrm{TiO}_{4}$ & $\mathrm{Co}_{2} \mathrm{TiO}_{4}$ & $\mathrm{Co}_{2} \mathrm{TiO}_{4}$ & $\mathrm{NiZnTiO}_{4}$ & $\mathrm{NiZnTiO}_{4}$ & $\mathrm{NiZnTiO}_{4}$ \\
\hline Average crystallite size, $\mathrm{nm}$ & 79.3 & 30.2 & 54.3 & 54.7 & 30.1 & 31.3 & 42.7 \\
\hline
\end{tabular}


Table 3 Sorption properties of sorbents: ZT, ZTCo and ZTNi

\begin{tabular}{|c|c|c|c|c|c|c|c|}
\hline Sorbent & $\mathrm{ZT}$ & ZTCo1 & ZTCo2 & ZTCo3 & ZTNi1 & ZTNi2 & ZTNi3 \\
\hline \multicolumn{8}{|c|}{ First sulfidation cycle } \\
\hline$C_{S}[\mathrm{gS} / 100 \mathrm{~g}]$ & 1.6 & 1.9 & 3.3 & 4.7 & 6.8 & 7.4 & 9.0 \\
\hline$K_{\mathrm{MeO}}[\%]$ & 12.5 & 12.6 & 22.0 & 32.8 & 38.7 & 44.2 & 56.3 \\
\hline \multicolumn{8}{|c|}{ Second sulfidation cycle } \\
\hline$C_{S}[\mathrm{gS} / 100 \mathrm{~g}]$ & 1.8 & 2.4 & 4.1 & 5.5 & 8.0 & 8.2 & 11.2 \\
\hline$K_{\mathrm{MeO}}[\%]$ & 14.5 & 15.5 & 27.6 & 38.3 & 45.5 & 49.5 & 70.2 \\
\hline \multicolumn{8}{|c|}{ Third sulfidation cycle } \\
\hline$C_{S}[\mathrm{gS} / 100 \mathrm{~g}]$ & 1.8 & 3.0 & 4.5 & 6.2 & 8.9 & 9.1 & 11.4 \\
\hline$K_{\mathrm{MeO}}[\%]$ & 14.5 & 19.2 & 30.5 & 43.2 & 51.9 & 54.7 & 71.4 \\
\hline
\end{tabular}

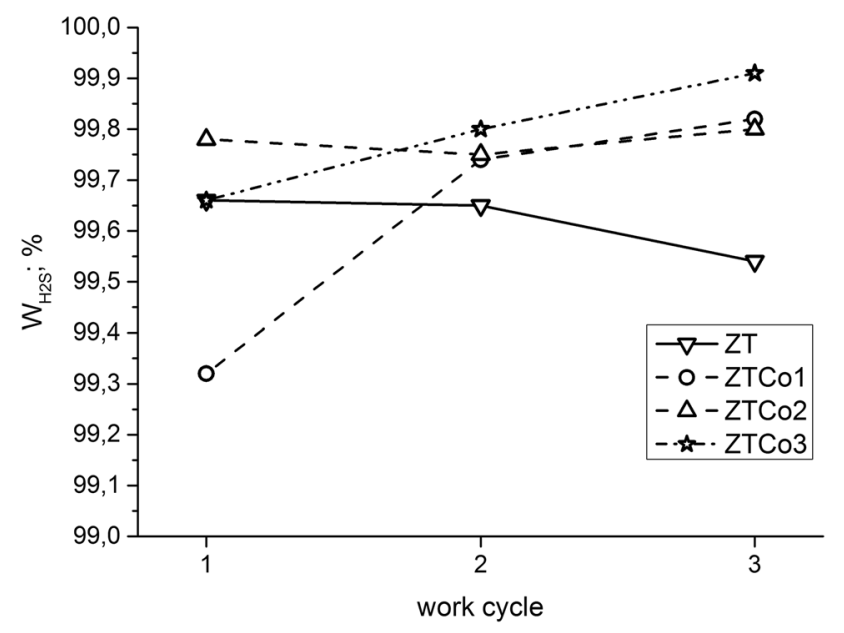

Fig. 3 Degree of $\mathrm{H}_{2} \mathrm{~S}$ removal by sorbents: ZT, ZTCo1, ZTCo2 and ZTCo3

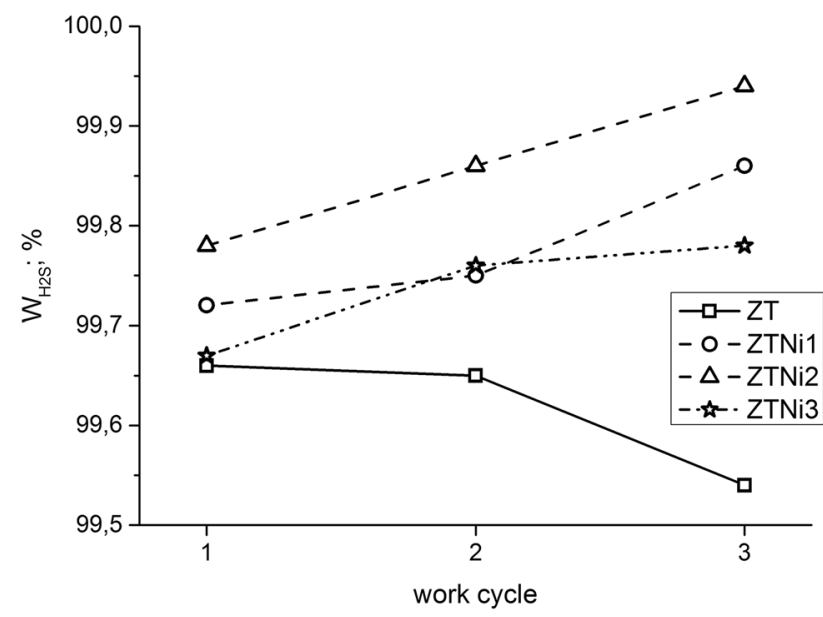

Fig. 4 Degree of $\mathrm{H}_{2} \mathrm{~S}$ removal by sorbents: ZT, ZTNi1, ZTNi2 and ZTNi3 and oxygen reacts with protons. In the a case of $\mathrm{Cu}$-doped $\mathrm{ZnO}$, sulphidation proceeds by a mechanism of inward growth: $\mathrm{S}^{2-}$ diffuses from the external surface to the internal $\mathrm{ZnO} / \mathrm{ZnS}$ interface, where it exchanges with $\mathrm{O}^{2-}$. This effect is attributed to a significant acceleration of sulfur transport through the $\mathrm{Cu}$-containing $\mathrm{ZnS}$ layer due to the presence of sulfur vacancies formed after the charge compensation of $\mathrm{Cu}^{1+}$ replacing $\mathrm{Zn}^{2+}$. We suppose that doping of $\mathrm{ZT}$ with $\mathrm{Co}(\mathrm{Ni})$ can also promote high mobility of sulfur anions in such a sorbent and consequently the conversion of the active components. Jun et al. (2004) also found that the addition of $\mathrm{Co}(\mathrm{Ni})$ to $\mathrm{ZT}$ increases the conversion rate of $\mathrm{ZnO}$ to $\mathrm{ZnS}$. Divergent results are reported regarding the effect of the active component content on the sorption capacity: exponential and linear growth; linear decrease (Wang et al. 2013; Akyurtlu and Akyurtlu 1995; Jun et al. 2004). These discrepancies probably arise from different process conditions and sulfates formation during regeneration (Girard et al. 2014; Wang et al. 2016).

For the ZT and ZTCo sorbents the degree of $\mathrm{H}_{2} \mathrm{~S}$ removal is higher than $99.2 \%$ (Fig. 3); in the case of ZT this parameter decreases with successive work cycles.

Sorption capacity of Ni-containing sorbents significantly exceeds the corresponding values found either for ZTCo or for ZT (Table 3). Additionally, ZTNi sorbents chemisorb $\mathrm{H}_{2} \mathrm{~S}$ more effectively than basic ZT or ZTCo sorbents. For the ZTCo sorbents, conversion of active components did not exceed $45 \%$ in any work cycle, while for ZTNi it was in the range 50-70\% (Table 3). This observation is convergent with results presented by Park et al. (2010). The degree of $\mathrm{H}_{2} \mathrm{~S}$ removal on ZTNi increases in subsequent cycles (Fig. 4).

The XRD patterns (Fig. 5) of sulphided ZTCo sorbents show that $\mathrm{TiO}_{2}$ is the dominating phase with an average crystallites size almost two times bigger than in the fresh material (Tables 2, 4). During sulphidation zinc present in the mixed metal oxides is converted into dispersed ZnS. X-Ray diffractogram of sulfided ZTCo1 shows no CoS peaks; however, they are seen in the XRD patterns of sulphided ZTCo2 and ZTCo3. Probably the lack of diffraction peaks of $\mathrm{CoS}$ results from its high dispersion 


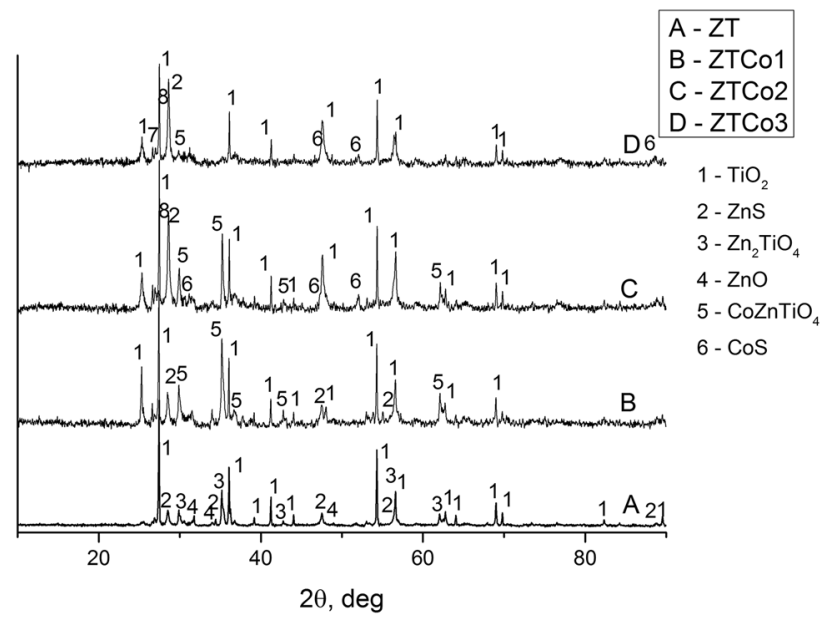

Fig. 5 XRD diffraction patterns of sulfided sorbents: ZT, ZTCo1, ZTCo2 and ZTCo3

or low crystallinity (Holder and Schaak 2019). The XRD patterns of all sulphided sorbents show peaks of mixed metal oxides that indicate incomplete conversion of an active metal oxide to sulphided forms (tests were termi-

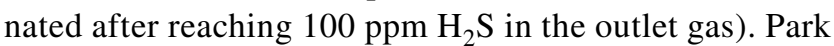
et al. (2010) and Jun et al. (2001) found $\mathrm{Co}_{9} \mathrm{~S}_{8}$ in the sulphided ZTC sorbent; however, their experiments were performed under different conditions.

The X-ray diffraction patterns of the sulphided ZTNi1 and ZTNi2 (Fig. 6) show strong peaks of $\mathrm{TiO}_{2}$ and intense signals of $\mathrm{ZnS}$ are also visible. Signals of $\mathrm{Ni}_{3} \mathrm{~S}_{2}$ are not seen, probably due to low intensity (noisiness) or high dispersion. The presence of zinc oxide and zinc titanate results from incomplete sorbent sulphidation. In the XRD pattern of sulphided ZTNi3, strong peaks of $\mathrm{ZnS}$ (average crystallite size $31.6 \mathrm{~nm}$ ) and less intense signals of $\mathrm{TiO}_{2}$ and $\mathrm{Ni}_{3} \mathrm{~S}_{2}$ are visible. Jun et al. (2001) reported that NiS in ZTNi sulphided at medium temperature is amorphous whereas Park et al. (2010) found $\mathrm{Ni}_{3} \mathrm{~S}_{4}$ in sulphided $\mathrm{NiO} / \mathrm{Al}_{2} \mathrm{O}_{3}$ with high $\mathrm{Ni}$ content $(50 \mathrm{wt} \%)$. It is considered that the phase composition of the sulphided $\mathrm{Ni}$ containing sorbents is determined by the sulphidation

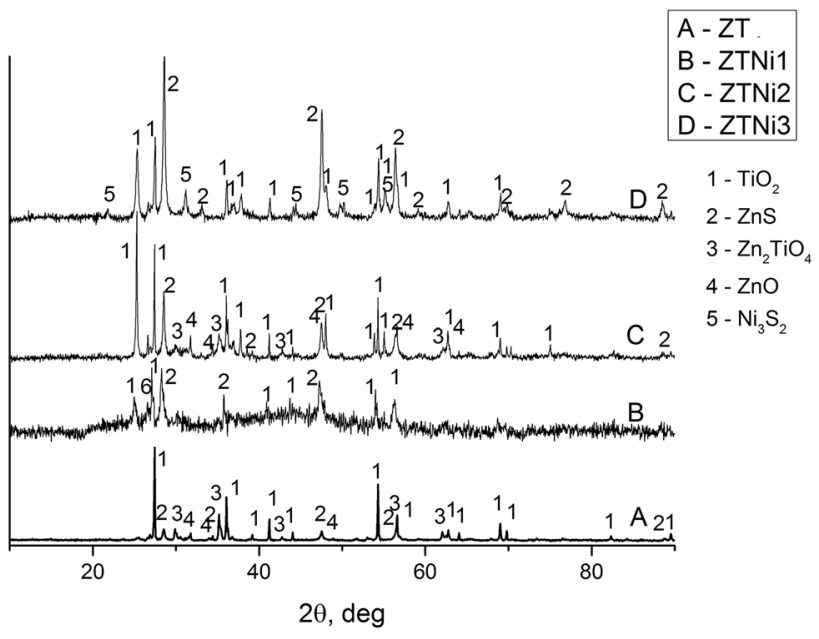

Fig. 6 XRD diffraction patterns of sulfided sorbents: ZT, ZTNi1, ZTNi2 and ZTNi3

parameters: temperature, pressure and $\mathrm{H}_{2} \mathrm{~S}$ concentration (Wang et al. 2016).

\section{Effect of cyclic operation on the sorbent texture}

The properties of sulphided sorbents (after the 4th sulphidation) are presented in Table 4. The total pore volume of ZTCo sorbents lowers after desulphurization tests, irrespective of the Co content, while the SSA increases almost twofold. This latter effect may be caused by a change of molar volume of the compounds adsorbing the sulfur. The molar volume of $\mathrm{ZnS}$ is 1.6 times larger than that of $\mathrm{ZnO}$, while in the case of $\mathrm{ZnSO}_{4}$ it is even 3.1 times larger (Lew et al. 1992). Cyclic changes in molar volume of a material may lead to its fracturing, loss of porosity and development of SSA.

The average pore size of fresh $\mathrm{ZTCo}(\mathrm{Ni})$ sorbents increases with the amount of $\mathrm{Co}(\mathrm{Ni})$ (Table 2), while after 4 cycles of sulphidation it is significantly lower (Table 4). The SSA and total pore volume of doped sorbents increase after sulphidation-more intensively for these with a higher dopant content.

Table 4 Properties of selected sulfided ZTCo and ZTNi sorbents (in the 4th cycle)

\begin{tabular}{llllll}
\hline Sorbent & ZT & ZTCo1 & ZTCo3 & ZTNi1 & ZTNi3 \\
\hline Total pore volume, $\mathrm{cm}^{3} / \mathrm{g}$ & 0.174 & 0.207 & 0.219 & 0.215 & 0.232 \\
Specific surface area, $\mathrm{m}^{2} / \mathrm{g}$ & 4.6 & 9.5 & 7.8 & 10.5 & 73.5 \\
Average pore diameter, $\mathrm{nm}$ & 176 & 98 & 121 & 62 \\
\hline Dominant phase & $\mathrm{TiO}_{2}$ & $\mathrm{TiO}_{2}$ & $\mathrm{TiO}_{2}$ & $\mathrm{TiO}_{2}$ & 73,8 \\
\hline Average crystallite size, $\mathrm{nm}$ & 87,3 & 87,0 & 78,7 & 31,6 \\
\hline
\end{tabular}


Table 5 Properties of selected regenerated ZTCo and ZTNi sorbents (at $923 \mathrm{~K}$; after the 3rd work cycle)

\begin{tabular}{|c|c|c|c|c|c|}
\hline Sorbent & $\mathrm{ZT}$ & ZTCo1 & ZTCo3 & ZTNi1 & ZTNi3 \\
\hline Total pore volume, $\mathrm{cm}^{3} / \mathrm{g}$ & 0.163 & 0.240 & 0.258 & 0.248 & 0.219 \\
\hline Specific surface area, $\mathrm{m}^{2} / \mathrm{g}$ & 3.7 & 10.6 & 8.0 & 11.9 & 10.7 \\
\hline Average pore diameter, $\mathrm{nm}$ & 193 & 68 & 77 & 73 & 76 \\
\hline Dominant phase & $\mathrm{TiO}_{2}$ & $\mathrm{Co}_{2} \mathrm{TiO}_{4}$ & $\mathrm{Co}_{2} \mathrm{TiO}_{4}$ & $\mathrm{TiO}_{2}$ & $\mathrm{TiO}_{2}$ \\
\hline Average crystallite size, $\mathrm{nm}$ & 77.9 & 32.6 & 46.6 & 49.9 & 58.1 \\
\hline
\end{tabular}

The SSA and total pore volume of Co $(\mathrm{Ni})$ doped ZT sorbents after $3 r d$ regeneration (three complete cycles of work) are higher compared to the corresponding values of fresh sorbents (Table 5) and are close to the corresponding values determined for sulfided materials.

The effect of sulphidation/regeneration cycles on the texture of the ZT sorbents is still ambiguous. Jung et al. (2005) reported results similar to ours: an increase of SSA of the ZT sorbent calcined at $923 \mathrm{~K}$ after 2 and 10 cycles of operation, while total porosity increased after 2 cycles and decreased significantly after 10 cycles. In the case of the sorbent calcined at $1273 \mathrm{~K}$, the SSA increased after 2 cycles of operation and decreased significantly after 10 cycles, while the total porosity decreased in both cases. On the other hand, Huang et al. (2008) report that sulphided ZT sorbent exhibit lower SSA and total pore volume due to $\mathrm{ZnS}$ formation (large molecular volume) while regenerated sorbent shows larger pore volume and SSA than fresh material.

The content of sulphates(VI) in the regenerated sorbents after 4 cycles of work was determined. It was found, that the fresh sorbents contain a small amount of $\mathrm{SO}_{4}{ }^{2-}$ (ca. $0.2 \mathrm{mg} \mathrm{SO}_{4}{ }^{2-} / \mathrm{g}$ ), probably introduced with the binder. After 4 cycles of work (isothermal regeneration at $873 \mathrm{~K}$ ), the
sulphates(VI) contents were $3.8 ; 1.8$ and $4.8 \mathrm{mg} \mathrm{SO}_{4}{ }^{2-} / \mathrm{g}$ respectively in ZT, ZTNi3 and in ZTCo3.

Comparison of representative images of the surface of fresh and regenerated sorbents shows that repeated cycles of sulphidation/regeneration do not change their morphology significantly (Figs. 7, 8, 9). On the surface of the fresh $\mathrm{ZT}$, large granules are observed; similar granules are visible on its surface after three cycles of regeneration, however they seem to be sintered. A similar conclusion can be drawn by comparing images of the surface of fresh and regenerated sorbents containing $\mathrm{Co}(\mathrm{Ni})$ : the surface of regenerated materials seems to be more solid and composed of build with finer grains.

\section{Regeneration}

During sulphidation, zinc embedded in the mixed metal oxides forms nanocrystalline $\mathrm{ZnS}$. Girard et al. (2014) reported that pure $\mathrm{ZnS}$ oxidizes (maximum of $\mathrm{SO}_{2}$ concentration in tail gas) at temperatures $>873 \mathrm{~K}$. In the case of $\mathrm{ZT}$ regeneration (procedure $\mathrm{I}$ ), oxidation of $\mathrm{ZnS}$ begins at a temperature of ca. $703 \mathrm{~K}$ (Fig. 10) - the concentration of $\mathrm{SO}_{2}$ in tail gas increases with temperature and already at

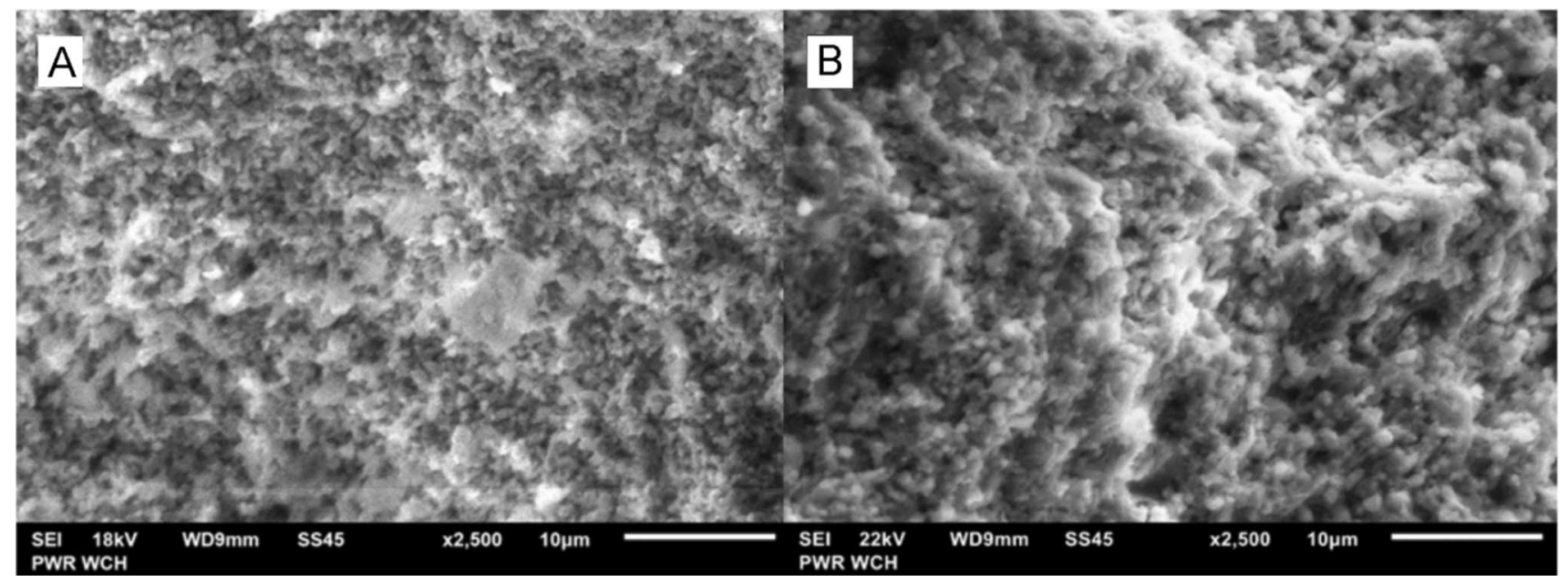

Fig. 7 SEM images of fresh (A) and regenerated (B) ZT sorbent 


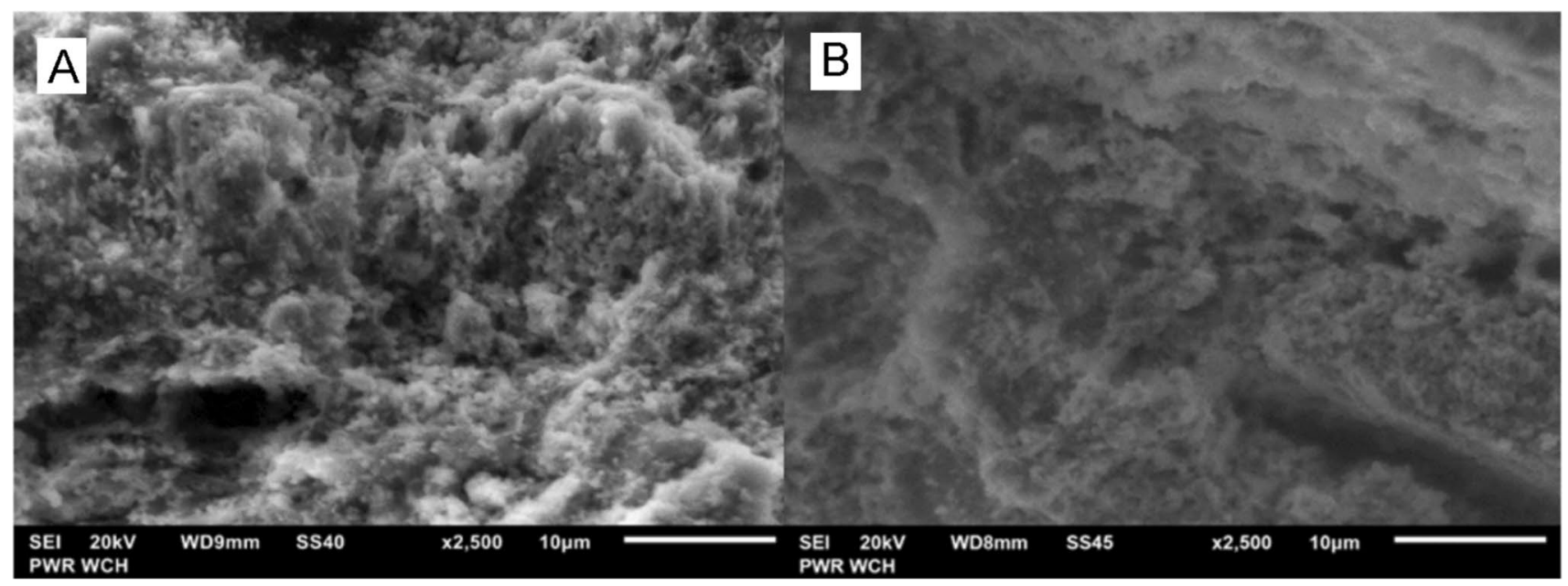

Fig. 8 SEM images of fresh (A) and regenerated (B) ZTCo3 sorbent

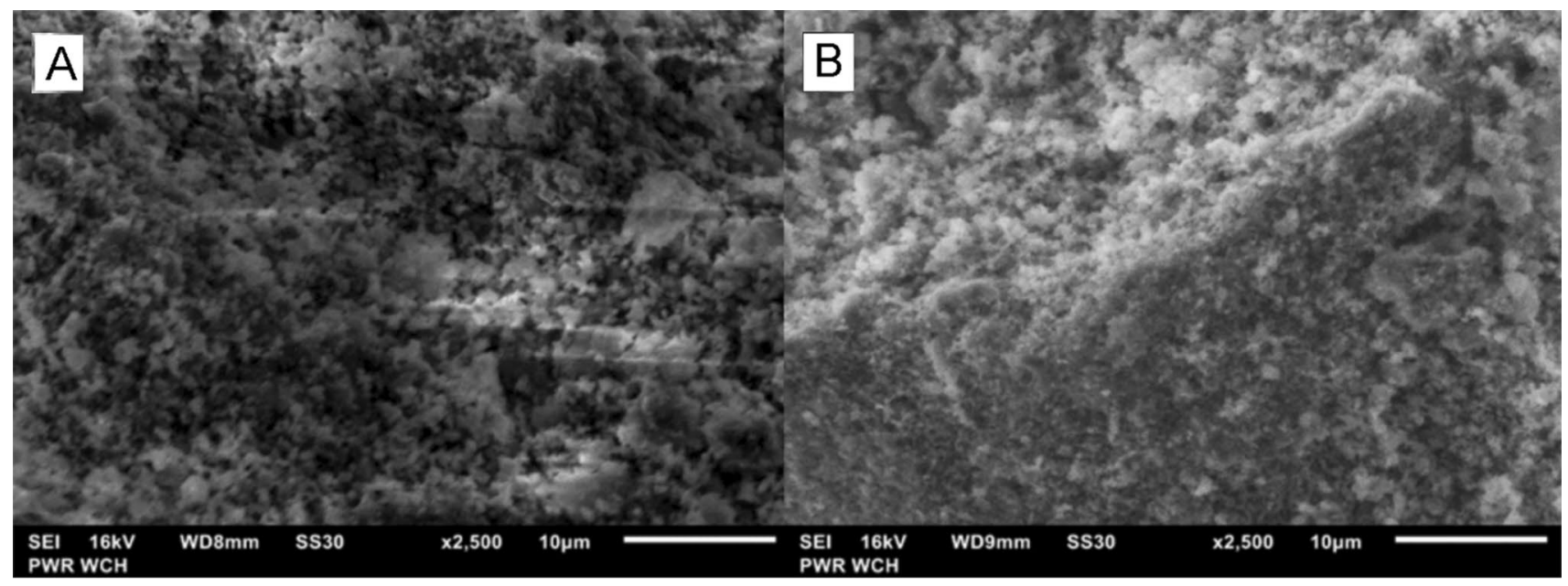

Fig. 9 SEM images of fresh (A) and regenerated (B) ZTNi3 sorbent

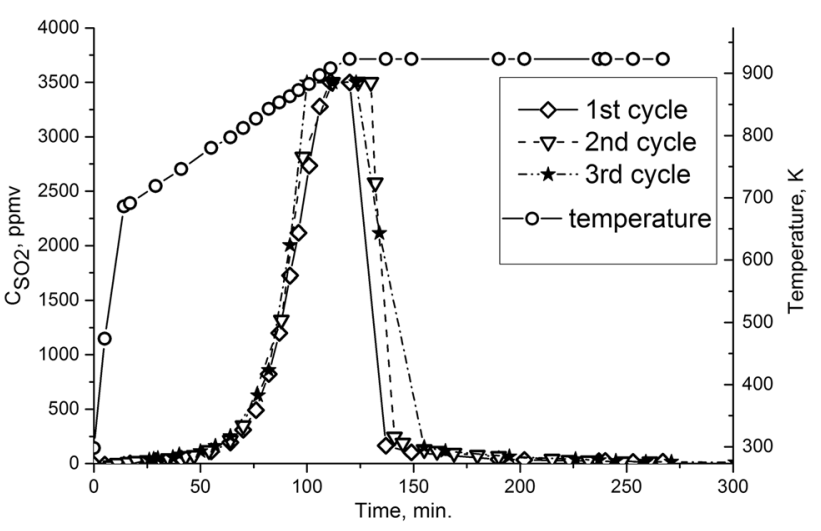

Fig. $10 \mathrm{SO}_{2}$ breakthrough curves during regeneration for sorbent $\mathrm{ZT}$. First procedure of regeneration

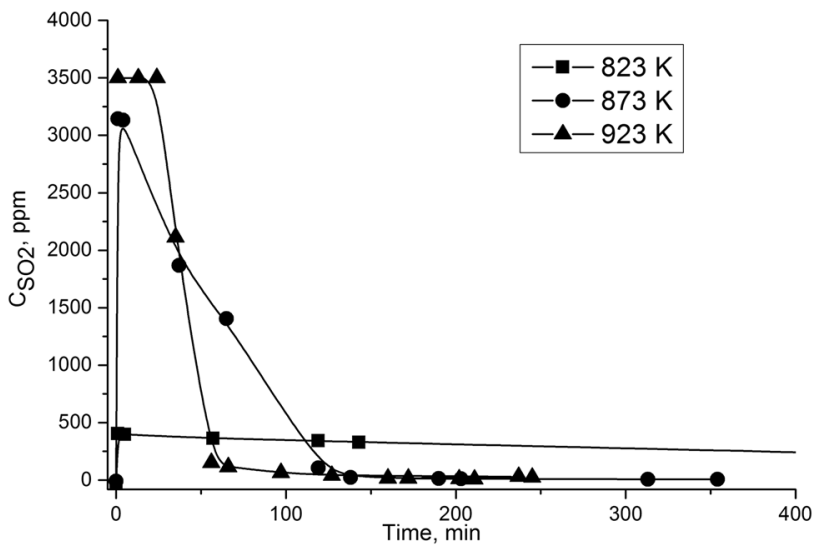

Fig. 11 The $\mathrm{SO}_{2}$ emission spectrum from the sorbent ZT. Effect of the regeneration temperature (isothermal) 


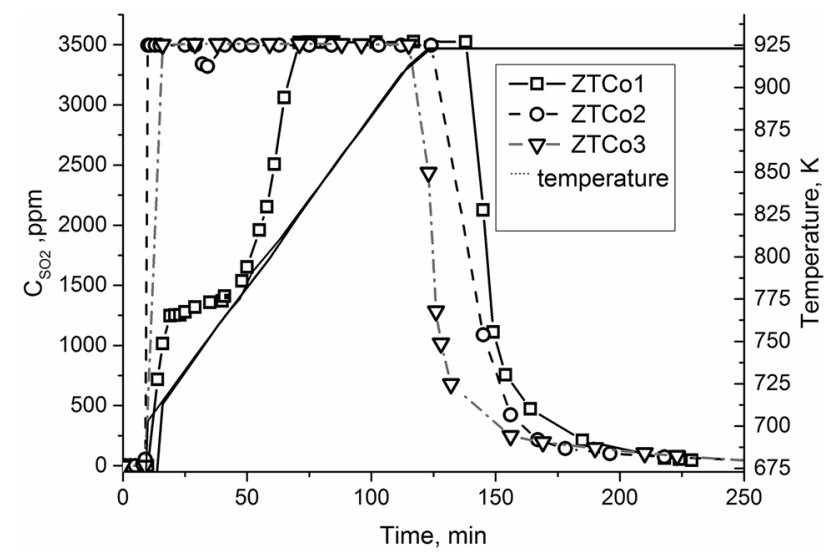

Fig. 12 Effect of Co content on $\mathrm{SO}_{2}$ emission during ZTCo regeneration. First procedure of regeneration

$\mathrm{T}>823 \mathrm{~K}$, under isothermal conditions (Fig. 11), oxidation takes places quite effectively.

The addition of Co into ZT does not significantly affect the initial temperature of reaction with oxygen during regeneration of the corresponding sorbent, but changes the concentration profile of $\mathrm{SO}_{2}$ in the tail gas (Fig. 12). Oxidation of sulphided ZTCo starts at ca. $693 \mathrm{~K}$, thus at a temperature similar to that determined for ZT. However unlike ZT, the concentration of $\mathrm{SO}_{2}$ in tail gas increases much faster with temperature and the Co sorbent contains more when it is higher. In the case of ZTCo1 (the lowest Co content), $\mathrm{SO}_{2}$ concentration stabilizes in ca. $30 \mathrm{~min}$ up to temperature of ca. $773 \mathrm{~K}$ and then rapidly increases (for the ZT sorbent a surge in $\mathrm{SO}_{2}$ concentration was observed at ca. $823 \mathrm{~K}$ ). For ZTCo2, already at ca. $693 \mathrm{~K}$ the concentration of $\mathrm{SO}_{2}$ is out of the analyser measuring range ( $3500 \mathrm{ppm})$, then decreases for a short period (until the temperature reaches $773 \mathrm{~K}$ ) and again significantly increases. In the case of ZTCo3, the concentration of $\mathrm{SO}_{2}$ throughout the whole regeneration period (up to the $923 \mathrm{~K}$ ) remains out of the measuring range.

Higher reactivity of Co sulfide relative to $\mathrm{ZnS}$ with oxygen makes regeneration last for a similar period of time as in the case of ZT, even though the former captured more sulfur (Table 3).

Tests of regeneration according to Procedure II (Fig. 13) were aimed to explain the effect of $\mathrm{CoS}$ oxidation on the apparent decrease of the $\mathrm{ZnS}$ regeneration temperature (whether there exists, e.g., bed overheating). During the first stage of ZTCo regeneration according to Procedure II, the $\mathrm{SO}_{2}$ emission increases with Co content. During the second step of regeneration the intensity of $\mathrm{SO}_{2}$ emissions increases with temperature. After the first step of regeneration (isothermally at $703 \mathrm{~K}$ ) ZTCo3 does not contain CoS, as was proven by XRD analysis (Fig. 16). Because the CoS was oxidized at lower temperature, one can therefore assume that emission of $\mathrm{SO}_{2}$ during the second step of regeneration is a

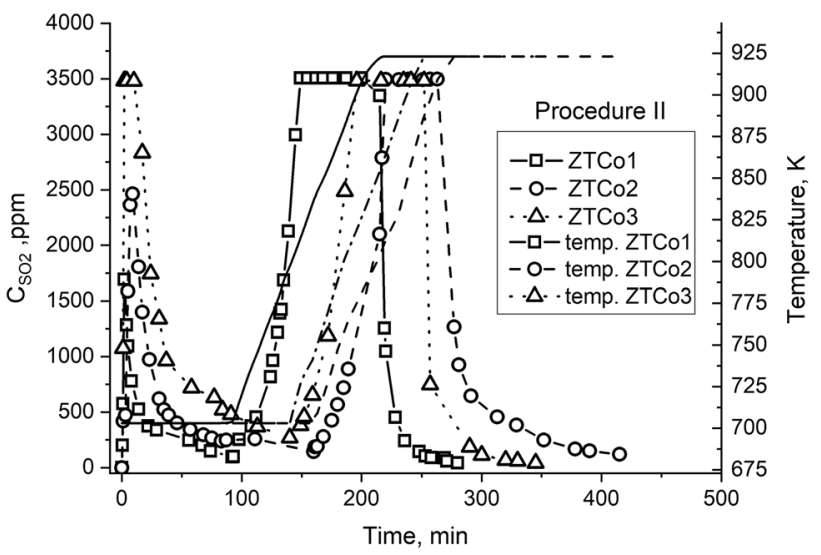

Fig. $13 \mathrm{SO}_{2}$ breakthrough curves for ZTCo sorbents. Second procedure of regeneration

result of $\mathrm{ZnS}$ oxidation. For all ZTCo sorbents regenerated according to Procedure II, emission of $\mathrm{SO}_{2}$ occurs intensely at ca. $793 \mathrm{~K}$ (for $\mathrm{ZT}$ a maximum of $\mathrm{SO}_{2}$ emission occurs at ca. $873 \mathrm{~K}$; Fig. 10) and this effect does not depend on the amount of incorporated Co. Addition of Co to ZT sorbent lowers the temperature of $\mathrm{ZnS}$ oxidation. Regeneration at low temperature $(703 \mathrm{~K}$ ) results in $\mathrm{CoS}$ oxidation. One can suppose that oxidation of $\mathrm{ZnS}$ in ZTCo occurs at lower temperatures than in the case of $\mathrm{ZnS}$ in $\mathrm{ZT}$, due to the catalytic effect of the Co and not due to the bed overheating.

Regardless of Ni content, the oxidation of sulphided ZTNi sorbents (Procedure I) starts at ca. $708 \mathrm{~K}$ (Fig. 14) and intense emission of $\mathrm{SO}_{2}$ occurs already at $723 \mathrm{~K}$. Decrease of $\mathrm{SO}_{2}$ concentration occurs after ca. $120 \mathrm{~min}$ of regeneration, independent of the amount of Ni. The profiles of $\mathrm{SO}_{2}$ concentration in tail gas are very similar for all these sorbents.

Regeneration of ZTNi according to Procedure II (Fig. 15) showed that the regeneration at $703 \mathrm{~K}$ is not effective the

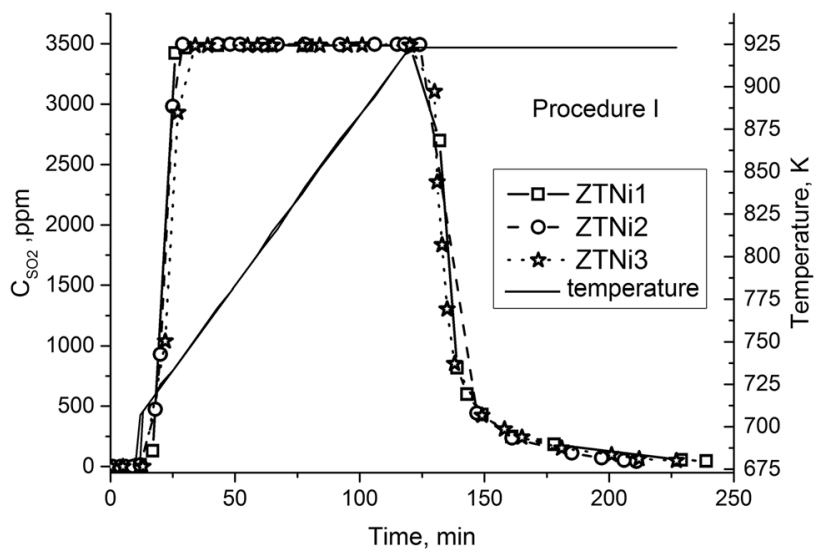

Fig. 14 Effect of Ni content on $\mathrm{SO}_{2}$ emission during ZTNi regeneration. First procedure of regeneration 


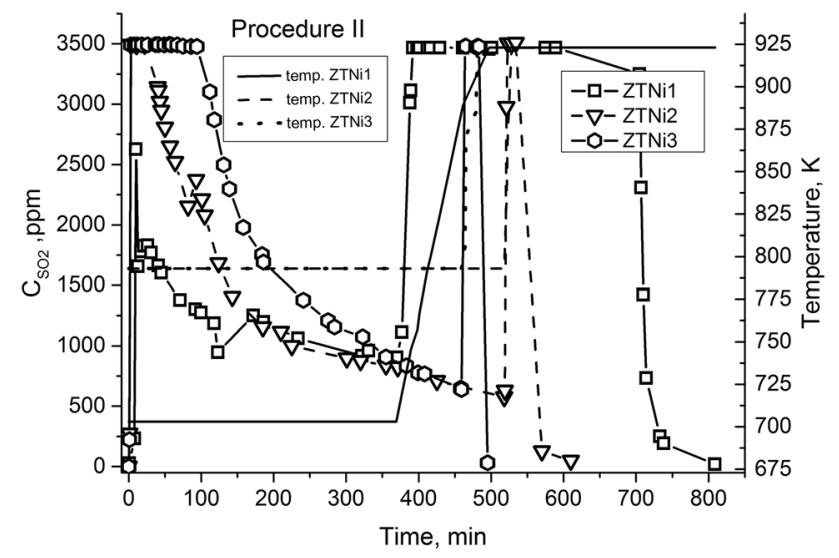

Fig. $15 \mathrm{SO}_{2}$ breakthrough curves for ZTNi sorbents. Second procedure of regeneration

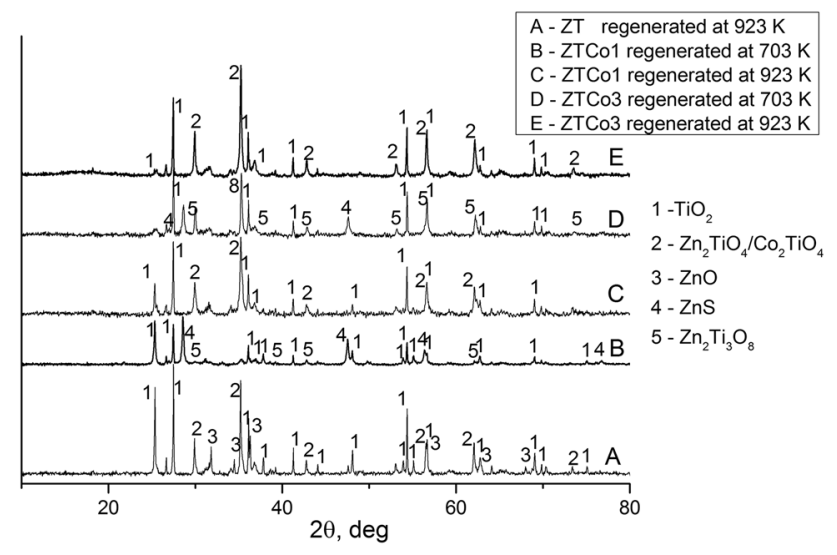

Fig. 16 XRD patterns of regenerated sorbents: ZT, ZTCo1 and ZTCo3

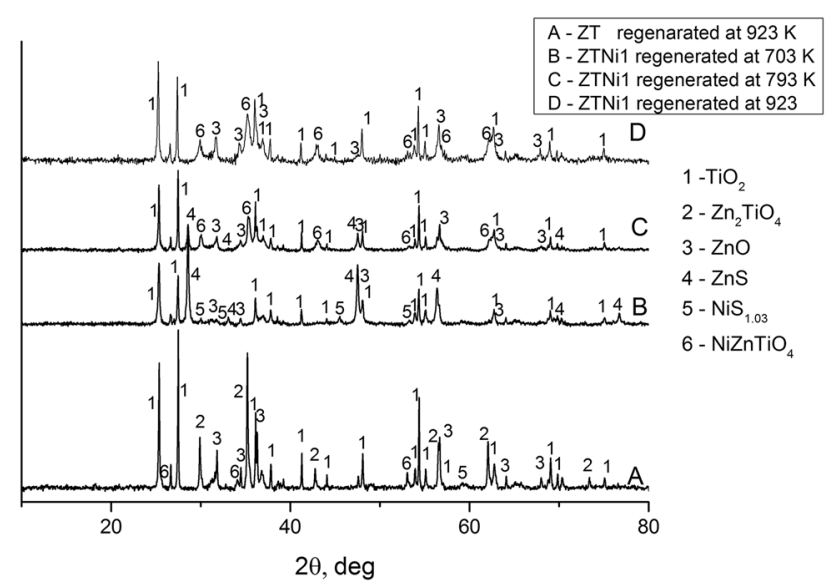

Fig. 17 XRD patterns of regenerated sorbents ZT and ZTNi1

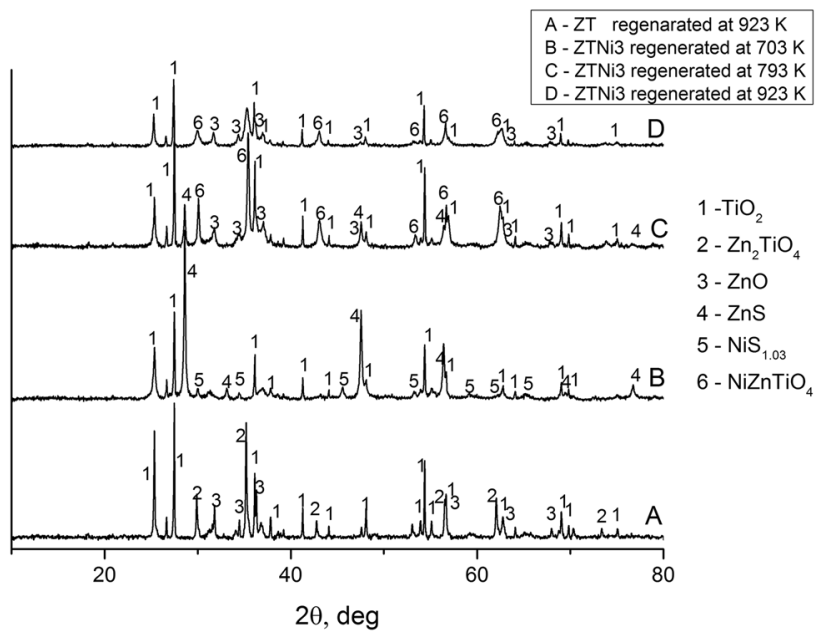

Fig. 18 XRD patterns of regenerated sorbents ZT and ZTNi3

maximum of $\mathrm{SO}_{2}$ concentration was ca. $2700 \mathrm{ppm}$ and, even after $370 \mathrm{~min}$, the concentration of $\mathrm{SO}_{2}$ was higher than $900 \mathrm{ppm}$. Furthermore, sorbent regenerated at this temperature still contains $\mathrm{NiS}_{1.03}$ (Fig. 17). These observations indicate a significant difference between sorbents doped with $\mathrm{Co}$ and $\mathrm{Ni}$, respectively. $703 \mathrm{~K}$ is a sufficient temperature to oxidize $\mathrm{CoS}$, while regeneration of $\mathrm{Ni}$-containing sorbent requires higher temperature. Therefore, the temperature of regeneration was raised up to $793 \mathrm{~K}$ (Fig. 15). At this temperature, at the initial stage of regeneration, the $\mathrm{SO}_{2}$ emission from ZTNi2 (and ZTNi3) is higher than $3500 \mathrm{ppm}$ and then under isothermal conditions, quickly lowers with time.

If the first stage of regeneration (Procedure II) was carried out at $703 \mathrm{~K}$, the concentration of $\mathrm{SO}_{2}$ in tail gas during the second stage of regeneration (higher temperatures) was very high and for ZTNil emission continued during ca. $400 \mathrm{~min}$. When the first stage of ZTNi2 and ZTNi3 regeneration was performed at $793 \mathrm{~K}$, the concentration of $\mathrm{SO}_{2}$ during the second stage of regeneration was low, despite higher (than for ZTNi1) "sulfur" load on both sorbents. For both temperature modes (703 K and $793 \mathrm{~K}$ ), just like in the case of ZTCo sorbents, in the second regeneration stage the temperature at which the oxidation of $\mathrm{ZnS}$ occurs intensely $(>3500 \mathrm{ppm}$ $\mathrm{SO}_{2}$ ), is lowered by $\mathrm{Ni}$ addition. A small emission of $\mathrm{SO}_{2}$ at 793 - $923 \mathrm{~K}$ observed for ZTNi2 and ZTNi3 (Fig. 15) suggests that $\mathrm{ZnS}$ oxidation in both sorbents (contrary to ZT (Fig. 11)) already occurs at $793 \mathrm{~K}$. One can state that $\mathrm{Ni}$ oxide lowers the temperature (catalytic effect) of $\mathrm{ZnS}$ oxidation in sulphided ZTNi in comparison to ZT.

The XRD patterns of ZTCo1 and ZTCo3 partially regenerated at $703 \mathrm{~K}$ show strong peaks of $\mathrm{ZnS}$ and weaker ones of $\mathrm{Zn}_{2} \mathrm{Ti}_{3} \mathrm{O}_{8}$. There are no peaks of CoS (Fig. 16b, d) and of Co oxides - the latter probably are highly dispersed. The presence of mixed oxide $\mathrm{Zn}_{2} \mathrm{Ti}_{3} \mathrm{O}_{8}$ indicates an incomplete 
conversion of this active component during the sulphidation step or it was re-formed during long-term regeneration.

In the X-ray diffractograms of ZTNi sorbents regenerated at $703 \mathrm{~K}$ (Figs. 17b, 18b), peaks of $\mathrm{TiO}_{2}, \mathrm{NiS}_{1.03}$ and $\mathrm{ZnS}$ (dominant) are present. It means that regeneration at $703 \mathrm{~K}$ is insufficient for effective oxidation of $\mathrm{Ni}$ sulfide and results in only poor $\mathrm{SO}_{2}$ emission (Fig. 15). The ZTNi sorbents regenerated at $793 \mathrm{~K}$ contain $\mathrm{ZnS}$ (low intensity peaks), $\mathrm{TiO}_{2}, \mathrm{ZnO}$; and $\mathrm{NiZnTiO}_{4}$. After regeneration at $923 \mathrm{~K}$ there is no $\mathrm{ZnS}$ (Figs. 17d,18d), while there are peaks arising from $\mathrm{ZnO}$ and $\mathrm{NiZnTiO}_{4}$, and peaks assigned to $\mathrm{TiO}_{2}$ are also observed.

Summarizing the above results forof sorbents regeneration, one can state that the addition of $\mathrm{Co}(\mathrm{Ni})$ oxides to $\mathrm{ZT}$ sorbent lowers the temperature of $\mathrm{ZnS}$ oxidation. This effect can be explained by the catalytic action of these oxides - they are known as oxidation catalysts-as well as by overheating of sorbent bed by heat produced during the oxidation of $\mathrm{Co}(\mathrm{Ni})$ sulfides (Heyes et al. 1982; Deng and Tüysüz 2014; Xie et al. 2010). Girard et al. (2015) reported that heat produced by oxidation of $\mathrm{MoS}_{2}$ (in ZnMo sorbents) overheats the sorbent bed and seemingly decreases the $\mathrm{ZnS}$ regeneration temperature. The lack of correlation between the amount of added $\mathrm{Co}(\mathrm{Ni})$ and the temperature at which sorbent oxidation begins (increase in heat release) suggests that $\mathrm{Co}(\mathrm{Ni})$ oxides catalyse $\mathrm{ZnS}$ oxidation. Regeneration according to Procedure I favours bed overheating, while under the conditions used in the Procedure II most of the $\mathrm{Co}(\mathrm{Ni})$ sulfides are oxidised at low temperatures. The temperature of intense regeneration of $\mathrm{ZnS}$ (high concentration of $\mathrm{SO}_{2}$ in the tail gas) in $\mathrm{ZTCo}(\mathrm{Ni})$ is still lower than in the case of ZT. The catalytic effect of $\mathrm{Co} / \mathrm{Ni}$ compounds on the temperature of regeneration is also suggested by Park et al. (2010) and Jun et al. (2001).

\section{Conclusions}

The addition of $\mathrm{Co}$ or $\mathrm{Ni}$ oxides to the $\mathrm{Zn}-\mathrm{Ti}$ sorbent improves its desulphurization properties and lowers the temperature of its regeneration as well. Oxides of $\mathrm{Co}(\mathrm{Ni})$ incorporated into $\mathrm{Zn}-\mathrm{Ti}$ sorbent form mixed metal oxides with a spinel-like structure and significantly improve $\mathrm{H}_{2} \mathrm{~S}$ sorption capacity, the degree of $\mathrm{H}_{2} \mathrm{~S}$ removal and the conversion of active components until the bed breakthrough. Sorption capacity of ZTCo(Ni) increases with the amount of incorporated $\mathrm{Co}(\mathrm{Ni})$. Addition of Ni leads to sorbents possessing higher sorption capacity than those of Co doped ones. Sulphidation of $\mathrm{Co}(\mathrm{Ni})$ doped $\mathrm{Zn}$-Ti sorbents results in decomposition of mixed metal oxides and formation of the corresponding metal sulfides and $\mathrm{TiO}_{2}$. The metal sulfides are highly dispersed in the whole volume of sorbent grains.
The addition of $\mathrm{Co}(\mathrm{Ni})$ oxides to $\mathrm{Zn}-\mathrm{Ti}$ sorbent affects also the course of regeneration of sulphided sorbent. Sulphides of $\mathrm{Co}(\mathrm{Ni})$ are oxidized at a lower temperature than $\mathrm{ZnS}$. Oxides of $\mathrm{Co}(\mathrm{Ni})$ formed during oxidation of sulphided sorbent catalyze the oxidation of $\mathrm{ZnS}$, so that it occurs at a lower temperature than in the case of undoped $\mathrm{Zn}-\mathrm{Ti}$ sorbent. Finally, mixed metal oxides containing $\mathrm{CoO}$ or $\mathrm{NiO}$ are formed again as a result of regeneration at $923 \mathrm{~K}$.

Acknowledgements The authors acknowledge financial support by a statutory activity subsidy from the Ministry of Science and Higher Education, Republic of Poland: for the Faculty of Chemistry of Wrocław University of Science and Technology (0401/0197/17).

\section{Declarations}

Conflict of interest The authors declare that the research is in compliance with ethical standards, and they have no conflict of interest.

Human and animal rights This article does not contain any studies with human participants or animals performed by any of the authors.

Open Access This article is licensed under a Creative Commons Attribution 4.0 International License, which permits use, sharing, adaptation, distribution and reproduction in any medium or format, as long as you give appropriate credit to the original author(s) and the source, provide a link to the Creative Commons licence, and indicate if changes were made. The images or other third party material in this article are included in the article's Creative Commons licence, unless indicated otherwise in a credit line to the material. If material is not included in the article's Creative Commons licence and your intended use is not permitted by statutory regulation or exceeds the permitted use, you will need to obtain permission directly from the copyright holder. To view a copy of this licence, visit http://creativecommons.org/licenses/by/4.0/.

\section{References}

Akyurtlu JF, Akyurtlu A (1995) Hot gas desulfurization with vanadium-promoted zinc ferrite sorbents. Gas Sep Purif 9:17-25

Atimtay AT, Harrison DP (1998) Desulfurization of hot coal gas. Springer, Berlin

Azároff V (1968) Elements of X-ray crystallography. McGraw-Hill, New York

Bezverkhy I, Skrzypski J, Safonova O, Bellat JP (2012) Sulfidation mechanism of pure and $\mathrm{Cu}$-doped $\mathrm{ZnO}$ nanoparticles at moderate temperature: TEM and in situ XRD studies. J Phys Chem 116:14423-14430

Chomiak M, Trawczyński J (2015) Effect of titania on the properties of $\mathrm{Zn}-\mathrm{Fe}-\mathrm{O}$ sorbents of hydrogen sulfide. Fuel Proc Technol 13:92-97

Deng X, Tüysüz H (2014) Co-oxide-based materials as water oxidation catalyst: recent progress and challenges. ACS Catal 4:3701-3714

Girard V, Baudot A, Chiche D, Bazer-Bachi D, Bounie Ch, Geantet C (2014) Rational selection of single oxide sorbents for syngas desulfurization regenerable at reduced temperature: thermochemical calculations and experimental study. Fuel 128:220-230

Girard V, Chiche D, Baudot A, Bazer-Bachi D, Clémençon I, Moreau $\mathrm{F}$, Geantet $\mathrm{Ch}$ (2015) Innovative low temperature regenerable zinc 
based mixed oxide sorbents for synthesis gas desulfurization. Fuel 140:453-461

Heyes CJ, Irwin JG, Johnson HA, Moss RL (1982) The catalytic oxidation of organic air pollutants part 1. Single metal oxide catalysts. J Chem Technol Biotechnol 32:1025-1033

Holder CF, Schaak ER (2019) Tutorial on powder X-ray diffraction for characterizing nanoscale materials. ACS Nano 13:7359-7365

Huang J, Zhao J, Wei X, Wang Y, Bu X (2008) Kinetic studies on the sulfidation and regeneration of zinc titanate desulfurization sorbent. Powder Technol 180:196-202

Hull S, Trawczyński J (2014) Steam reforming of ethanol on zinc containing catalysts with spinel structure. Int J Hydrogen Energy 39:4259-4265

Jun HK, Lee TJ, Ryu SO, Kim JC (2001) A study of Zn-Ti-based $\mathrm{H}_{2} \mathrm{~S}$ removal sorbents promoted with cobalt oxides. Ind Eng Chem Res 40:3547-3556

Jun HK, Koo JH, Lee TJ, Ryu SO, Yi CK, Ryu CK, Kim JC (2004) A study of $\mathrm{Zn}$-Ti-based $\mathrm{H}_{2} \mathrm{~S}$ removal sorbents promoted with cobalt and nickel oxides. Energy Fuels 18:41-48

Jung SY, Jun WK, Lee SJ, Lee TJ, Ryu ChK, Kim JCh (2005) Improvement of the desulfurization technology and regeneration properties through the control of pore structures of the $\mathrm{Zn}$-Ti-based $\mathrm{H}_{2} \mathrm{~S}$ removal sorbents. Environ Sci Technol 39:9324-9330

Lew S, Jothimurugesan K, Flytzani-Stephanopoulos M (1989) Hightemperature $\mathrm{H}_{2} \mathrm{~S}$ removal from fuel gases by regenerable zinc oxide-titanium dioxide sorbents. Ind Eng Chem Res 28:535-541

Lew S, Sarofim AF, Flytzani-Stephanopoulos M (1992) The reduction of zinc titanate and zinc oxide solids. Chem Eng Sci 47:1421-1431

Meng X, De Jong W, Pal R, Verkooijen AHM (2010) In bed and downstream hot gas desulphurization during solid fuel gasification: a review. Fuel Proc Technol 91:964-981
Park JJ, Jung SY, Park CG, Lee SC, Kim JC (2010) A study on the regenerable $\mathrm{Co}$ and $\mathrm{Ni}$-based sorbents to remove hydrogen sulfide at middle temperature. Top Catal 53:635-640

Pineda M, Fierro JLG, Palacios JM, Cilleruelo C, Garcia E, Ibarra JV (1997) Characterization of zinc oxide and zinc ferrite doped with $\mathrm{Ti}$ or $\mathrm{Cu}$ as sorbents for hot gas desulphurization. Appl Surf Sci 119:1-10

US Department of Energy, National Energy Technology Laboratory (2015), Washington DC. https://www.netl.doe.gov/File\%20Lib rary/Events/2015/gas-ccbtl-proceedings/Gasification-2015-Works hop-Gupta-Presentation-FINAL.pdf. Accessed 10 Aug 2015

Wang J, Liang B, Parnas R (2013) Manganase-based regenerable sorbents for high temperature $\mathrm{H}_{2} \mathrm{~S}$ removal. Fuel 107:539-546

Wang J, Jia Z, Wang Q, Zhao S, Xu Z, Yang W, Frenkel AI (2016) XAFS characterization of industrial catalysts: in situ study of phase transformation of nickel sulfide. J Phys Conf Ser 712:012145

Washburn EW (1921) The Dynamics of Capillary Flow. Phys Rev $17: 273-283$

Xie Y, Dong F, Heinbuch S, Rocca JJ, Bernstein ER (2010) Oxidation reactions on neutralcobalt oxide clusters: experimental and theoretical studies. Phys Chem 12:947-959

Zdrazil M (2001) Supported $\mathrm{MoO}_{3}$ catalysts: preparation by the new "slurry impregnation" method and activity in hydrodesulphurization. Cat Today 65:301-306

Publisher's Note Springer Nature remains neutral with regard to jurisdictional claims in published maps and institutional affiliations. 